\title{
SPORT VERSUS EMPLOYEE PERFORMANCE
}

Hvizdová Eva, PhDr. Ing., Ph.D, MBA, Vice-rektor. College of International Business ISM Slovakia in Prešov, Duchnovicovo námestie 1, Prešov 080 01, Slovakia.

e-mail: hvizdova@ismpo.sk,

ORCID ID 0000-0002-1348-2278

Brezanská Jana, Ing., MBA, Sales and CRM specialist, Jirásková 56, Prešov 080 05, Slovakia e-mail: j.brezanska@gmail.com

\begin{abstract}
The aim of the paper is to point out the importance of the presence of sport for the work performance of employees. The survey is focused on the analysis and comparison of work performance of employees who regularly play sports with those who do not play sports at all, or rarely. The influence of physical activity is discussed in aspects such as motivation, work efficiency, coping with stressful situations, creativity and the overall mood of the employee. The results of the survey confirmed a significant linear correlation between the impact of sport on creativity and positive mood. The proposed action plan for physical activities to support sports in the workplace is focused on a healthy lifestyle and health prevention.
\end{abstract}

Keywords: work performance, physical activity, motivation, work efficiency, coping with stressful situations.

\section{СПОРТ ЯК ПІДВИЩЕННЯ ПРОДУКТИВНОСТІ ПРАЦІ СПІВРОБІТНИКІВ}

Hvizdová Eva, PhDr. Ing., Ph.D, MBA, Vice-rektor. College of International Business ISM Slovakia in Prešov, Duchnovicovo námestie 1, Prešov 080 01, Slovakia.

e-mail: hvizdova@ismpo.sk,

ORCID ID 0000-0002-1348-2278

Brezanská Jana, Ing., MBA, Sales and CRM specialist, Jirásková 56, Prešov 080 05, Slovakia e-mail: j.brezanska@gmail.com

\begin{abstract}
Анотація. Метою написання статті є звернути увагу на важливість присутності спорту для підвищення продуктивності праці співробітників. Проведене опитування зосереджено на аналізі та порівнянні результатів роботи працівників, які регулярно займаються спортом, з тими, хто взагалі або рідко займається спортом. Вплив фізичної активності обговорюється в таких аспектах, як мотивачія, ефективність роботи, подолання стресових ситуацій, творчість та загальний настрій працівників. Результати опитування підтвердили значну лінійну кореляцію між впливом спорту на творчість та позитивним настроєм. Пропонований план дій щзодо фізичних навантажень для підтримки спорту на робочому місці орієнтований на здоровий спосіб життя та профілактику здоров'я.

Ключові слова: продуктивність праці, фізична активність, мотивачія, ефективність роботи співробітників, подолання стресових ситуаиій.
\end{abstract}

JEL Classification: Z 200, J240

Introduction. In addition to its products and services, the core of every company is also its employees. A productive and healthy employee sees job opportunities where others see obstacles, focuses on solutions, not problems, and completes assigned tasks in a timely manner.

Such an employee can be a positive example for others; managers should respect such employees and be able to appreciate them appropriately. Ideally, there should be as many productive and healthy workers in the organization as possible in order to achieve that such behaviour is considered a standard. In today's turbulent times of the Fourth Industrial Revolution, when the gap between labour supply and demand is widening, employee turnover is increasing, work organizations and their human resources managers must make more efforts to motivate employees as well as their health.

For the youngest generations, it is an essential element that can keep them in the company. According to the latest statistics, the youngest generations $\mathrm{Z}$ and $\mathrm{Y}$ change jobs much more often than previous generations, after about 9 months, which means that the element of employee loyalty to the employer disappears. There is a trend for employers to retain and attract good employees through various benefits, but unfortunately this strategy is not always successful in the long run. Some organizations and their managers often face the question of how to ensure that the employee 
is motivated, positive, productive, not subject to unnecessarily stressful situations and is also creative and bringing new ideas to the company.

The answer may be easier than we would think, bringing more sports and physical activities to the workplace. Because movement is one of the activities that benefits our brain in surprise. Thanks to physical activity, we feel better, we improve our memory, resistance to stress, we increase our ability to concentrate, creativity, motivation and, last but not least, it is proven that it also increases intelligence.

The aim of the paper is to point out the importance of the impact of sport on the employee's work performance.

Movement and work performance. Exercise is a physical activity that is planned, structured and repeated in order to improve the condition of some parts of the body. Exercise serves to improve health, fitness and is also an important means of physical rehabilitation.

Other domestic sources [9] describe movement as life, movement is health. Exercise is a simple, publicly available tool that can improve health and quality of life. Exercise is the continuous use of the body to stay strong, flexible and healthy. For comparison, the WHO defines physical movement as any movement that the body produces through skeletal muscle. "According to basic European health indicators, physical activity is one of the most important determinants of health. Insufficient physical activity increases the probability of reducing the body's resistance and deteriorating health. Its effects are comparable to the effects of risk factors such as smoking, high levels of total cholesterol, high blood pressure and are also attributed to the more adverse effects on the human body" [5].

Sport is a significant and influential social phenomenon today. It has become a content of work and leisure, so it has become a profession and entertainment for a large number of people. In defining the term sport, we relied on information from Act no. 440/2015 Coll. [11] on sport and amending certain laws, which defines sport as all forms of physical activity which, through occasional participation or organized participation, lead to the demonstration or increase of physical fitness and mental well-being, form social ties or enable results to be achieved in competitions at all levels. In addition to the health benefits, sport also includes an educational aspect and improves some of the soft skills that are desirable in the world of work today. Sport also teaches us to develop the following qualities: develops team spirit, develops leadership skills, develops endurance, increases concentration, helps to achieve flow, present moment, teaches planning, teaches honesty and sincerity, helps to manage stress, improves observation and analytical skills, develops strategic thinking [3].

The European Union, as an organization, is also aware of the importance of the presence of sport and physical activities. Based on this awareness, it prepared the document Strategy of Physical Activity for WHO European Region for the years 2016 - 2025 [13]. The document also comments on the issue of physical activities in the workplace, which should gradually become an integrated part of the corporate subculture.

The European Union recommends that Member States provide opportunities and advice on physical activity and active lifestyles for work organizations. Member States should consider taking appropriate measures to promote the active commuting and use of public transport on the way to work. These measures may include regulations, guidelines or financial incentives for organizations, in particular, for example, bicycle storage, bicycle racks, changing rooms, showers and appropriate public support options for employers. Organizations should consider allowing employees to perform more physical activity during the normal working day. These measures may include activities aimed at organizing the workplace, such as the provision of adjustable tables or promotional signs on the stairs to encourage their use, or regular breaks during the day to allow physical activity, individually or collectively. The team can also tighten up during the plank challenge, in which employees can, for example, compare times for how long they will stay in the plank position. Other recommended measures include, providing employees with membership in a gym, sports club or, for larger companies, their own corporate sports facilities, organizing sports events, or corporate sports days. The implementation of the above-mentioned regulations could be supported by health and safety workers at work. Particular attention should be paid to the different needs of different types of workplaces, sectors and employees, including the informal sector and the self-employed. In implementing the measures, efforts must be made to ensure that the promotion of physical activity in the workplace does not increase existing inequalities in the workplace. Targeted programs and interventions may be needed to tailor specific needs to manual workers, employees in the informal sector or in a low-income environment. As a result, Member States should place particular emphasis on reaching all employees, including the socially 
disadvantaged [12]. By integrating concepts in evolutionary medicine with concepts from clinical and cognitive neuroscience, a new model of adaptive capacity has been proposed that explains how and why exercise protects the brain throughout life, leading to improved cognitive function and the potential for successful cognitive aging. The model suggests that our evolutionary history as cognitively involved endurance athletes during foraging has led to improved neural responses to exercise [8]. Endurance exercise is one of the few physiological stimuli that has been shown to increase the production of new neurons in the brain, which is of course related to the improvement of memory or other brain functions [9].

Work motivation is very important for every employee in every job position. More than seven out of ten employees in the UK said that their employers were more motivating. These findings came from a new study by Reward Gateway, which suggests that alarming effects of demotivation on employees include, for example, mood deterioration in $60 \%$ of respondents, reduced productivity in $48 \%$ of respondents, reported a decline in mental health of up to $46 \%$ and $40 \%$. More than a quarter of $26 \%$ say their relationships with family and friends suffer and 2 out of 10 admit that they drink more alcohol if they do not feel motivated at work. The study also found that if an employee does not feel motivated to work, he or she is most likely to be compensated for financial rewards, good working relationships, or other factors such as social status. Those who said they felt extremely motivated justified it with respect and good working relationships [1]. Exercise not only improves our physical condition, but also teaches our body to better manage stress, for example at work [6].

A good and positive mood attracts other people, a positive employee is usually popular with others, others like to work with him, looking for his company in the team. Repeated scientific research has confirmed that regular physical activity is responsible not only for happier and more satisfied people, but even for changes in basic character traits [2].

Analysis of the questionnaire survey. The article is based on the hypothesis that sports and physical activities, among other things, have a positive effect on the employee's work performance. There is a presumption of interdependent values, the more physical activity, the more productive employees are than those who have less physical activity. To confirm or refute the hypothesis, we used the method of analysis of questionnaire data, which we obtained as an output from the survey. Questions were asked in order to find a correlation between physical activities and selected indicators.

The last question was open and aimed at obtaining recommendations from respondents. The questionnaire addressed a total of 148 respondents, with a predominance of women $68.1 \%$ compared to men $31,9 \%$. By age, the respondents in these age categories were young people from 19 to 25 years in the number of $19,7 \%$, the second category consisted of respondents from 26 to 35 years in the number of $29,9 \%$, the third most numerous category consisted of people from 36 to 45 years in the number of $34,7 \%$, the fourth category consisted of respondents aged 46 to 55 in the number of $13,6 \%$ and the last category was focused on respondents aged 55 and over, this category reached the lowest percentage of $2 \%$ of respondents.

One of the first questions in the questionnaire was to find out how often respondents perform sports activities. The question was asked as follows: "Do you play sports, do exercise or do physical activities regularly?" Surprisingly, most $3 / 4$ respondents stated that they perform physical activities more than 3 times a week, $11 \%$ of respondents perform physical activities once a week. The frequency was sometimes stated by $3 \%$ of respondents, occasionally by $9 \%$ of respondents and 2 $\%$ of respondents do not perform any sports and physical activities. One question was opened so that we could find out or inspire when implementing the results in practice, what physical activities are performed by the respondents.

The aim of the question was also a certain change in the style of the questions, so that the respondents did not consider the questionnaire monotonous and were given the opportunity to express themselves. Among these responses, anaerobic activities such as running, cycling, walking, hiking, and cardio exercise were the most common responses. In addition to these, yoga, strength training, Pilates and other sports activities were often mentioned, some unique ones such as shooting. When asked: "Do you feel health problems that would cause you everyday complications in your job?" $67 \%$ of respondents consider their health to be problem-free, $20 \%$ of respondents sometimes experience health problems and $13 \%$ admitted health problems that cause them complications even when performing of employment.

In a selective question, we learned what type of job position the respondents currently hold in the organization, regardless of their job focus. The aim of this question was to find out how many $\%$ of respondents hold a managerial position $-14 \%$, how many $\%$ of respondents work as an 
employee in the organization $69 \%$, how many respondents are self-employed $14 \%$ and how many $\%$ of respondents are currently not working $6 \%$. When asking the question, we thought of the hypothesis that sport also has an impact on career growth. Based on the obtained data, we cannot confirm the hypothesis, but also refute it. Because of all the answers, $14 \%$ of the respondents stated that they work in a managerial position in the organization and $11 \%$ of the respondents work through their own business. Together, this represents $1 / 4$ of respondents.

In the primary survey in the form of a questionnaire, we wanted to find out how physical activities affect selected indicators such as job satisfaction, work motivation, efficiency, attention, stress, positive mood and creativity.

Job satisfaction is a key element for every employee. If the employee is satisfied, there is a presumption that he performs his work well and responsibly. The question in the survey was: "How do you evaluate the job you perform in terms of your personal satisfaction?" Respondents were able to answer this question using a 3-point Liker scale, where 1 meant satisfaction with the job, my work is personally fun and describes, on the contrary 3 meant dissatisfaction I often think about a change of job. We assumed that more physical movement means higher satisfaction. Half of the respondents $51 \%$ stated that they were satisfied with the workload, $38 \%$ of respondents answered the question neutrally and $11 \%$ stated a feeling of dissatisfaction with the workload. From the given results we can conclude that there is a certain correlation between the frequency of physical activities and job satisfaction, but it is not applicable to all.

Motivation at work is an interesting topic that has been and is being studied by several psychologists. One of them, the psychologist Herzberg, came up with his Herzberg motivation theory, according to which the manager can influence hygienic factors at the employee level, those that eliminate dissatisfaction such as salary, benefits, relationships, working conditions and job security, and motivators that create satisfaction are intangible nature such as recognition, praise, creativity, personal growth and career growth. At the same time motivators have a greater influence on work motivation, though Herzberg held the idea that money does not motivate. The emergence of this theory increased the interest in business psychology, work-enriching programs, as well as aroused interest in internal motivation at work [7]. In the survey, we asked respondents how they would evaluate their internal motivation in performing the work they perform. Even on this issue, we assumed that physical activities can have some effect on internal motivation at work. Respondents could answer this question using a 3-point Liker scale, where 1 meant I was very motivated, work brings me joy, I enjoy every day at work, on the contrary, 3 meant I no longer feel motivation, I work mainly for financial security. Most respondents $44 \%$ pointed to neutral feelings when experiencing internal motivation at work, $40 \%$ of respondents stated strong motivation at work, work brings them joy and they enjoy every day at work. On the other hand, $16 \%$ of respondents stated that they no longer feel motivated and do work mainly for financial security. The data show that, as Herzberg has already defined, there are several motivators and hygienic factors that have a positive effect on motivation at work. The role of managers is to find and implement in practice a suitable mix of tools that would achieve success for more employees and thus achieve a collective increase in motivation.

Efficiency, in other words also productivity and work efficiency, is the ratio of the units of input and output of work activity. The goal of the organization is to achieve the highest possible efficiency at work, using various tools, such as a clear definition of the organization's goals, elimination of redundant processes, process automation. When it came to the issue of efficiency, we were curious whether employees who play regular sports also achieve higher efficiency in their work activities, as their brains are regularly stimulated. The question was: How would you rate your efficiency in doing the job? Respondents could also answer this question using the 3-point Liker scale, where 1 meant I work very efficiently during the whole working time, I consider myself an executive, on the contrary 3 meant my efficiency at work could be much better, I often find myself procrastinating in work. We evaluate the answers positively, as up to $55 \%$ of respondents, which makes up more than half of the answers, said that they work very efficiently during the whole working time and consider themselves as executives. $36 \%$ of respondents had a neutral attitude to the question. On the contrary, only $9 \%$ of respondents said that their efficiency at work could be much better, as they often find themselves procrastinating at work.

Attention is an important part of being able to focus on one thing and not be disturbed by others. The ability to quickly identify selected information and ignore irrelevant information is called selective attention. Selective attention is an important part of the ability to concentrate and is considered an important social trait, not just in the workplace. The effect of physical activity on selective attention and ability to concentrate was determined using the Eriksen Flanker test, which 
consists of five arrows on the screen. The task of this test is to find out as quickly as possible in which direction the arrow in the middle points. The organizers measured not only the attention of the test participants, but also the level of physical activity and fitness. The test showed that the results were better in participants with higher physical activity [4]. We wanted to confirm the results of Eriksen's test with another question, which sounded as follows: During the performance of my work, I am attentive and focused, mistakes from "inattention" do not happen to me often, do you agree with the statement? Respondents could answer the question using a 3-point Liker scale, where 1 meant I agree, my attention and concentration is high, when I work I reach a state of "flow", on the contrary 3 do not agree, it often happens that I think of something other than the work at that moment I am performing. Survey participants, consisting of a majority of respondents who play sports regularly, provided the following answers: $52 \%$ of respondents said they get a lot of attention at work, $42 \%$ of respondents said they were neutral and $6 \%$ of respondents said they often thought of something other than the work they were doing. Based on the answers, the positive correlation was not confirmed, as it is not certain that physical condition improves the ability to concentrate, it can easily be the other way around. Those who like sports have their attention under control.

Stress is part of our work as well as our personal lives. Those who are better able to manage stress in the workplace can have a certain advantage in building a career, because the feeling of threat, increased pulse and heat surge in presentations bypasses him. It is proven that the most effective remedy for stress is physical activity, physical activity is an effective method of preventing and combating stress. What the correlation of active movement and selected indicators is. Scientists report the following statement: With increasing fitness, our body is also learning to better manage stress. We also wanted to verify the statement in the survey with the question: I manage stressful situations at work with foresight, they do not cause me a problem, do you agree with the given statement? Respondents could also answer this question using the 3-point Liker scale, where 1 meant I agree, I am not subject to stressful situations at work, on the contrary, 3 meant I disagree, I often experience stress at work. Respondents' answers are:

$55 \%$ of them agree with the statement that I am not subject to stressful situations at work, $36 \%$ were neutral and $9 \%$ of respondents often experience stress at work. Even in this case, the positive direct correlation between the frequency of sports activities and the stress experienced by our respondents was not directly confirmed.

A positive mood attracts people's attention. It is said that life is easier with a good mood. This also applies at work, employees who are positive, are usually popular in the team and sought by other colleagues to solve not only problems but also other topics. According to scientific studies, more physical activity also affects mood. The question in the survey was as follows: During the working day I am usually in a positive mood, do you agree with the statement? Respondents could also answer this question using the 3-point Liker scale, where 1 meant I agree, a positive mood accompanies me for most of the day, on the contrary, 3 meant I disagree, I could be more positive. The answers provided the best correlation among the above factors between the frequency of sports activities and the evaluation of the positive mood of the respondents. I agree with the statement, a positive mood accompanies me during the whole working day, up to $63 \%$ of respondents agreed, $30 \%$ of respondents stated neutral feelings, on the contrary, $7 \%$ of respondents did not agree with this statement.

Creativity, creative thinking is one of the foundations of a manager's success. Creativity can be increased thanks to exercise, but too much exhaustion does not help it. I consider myself being creative and other people around me also consider me as a creative person, do you agree with the statement? Respondents answered as follows: $53 \%$ of respondents consider themselves creative, $40 \%$ of respondents were neutral about the question and $7 \%$ of respondents said that new ideas are more difficult to come up with. The last question in the questionnaire was open and focused on the respondents' recommendations. The question was: Would you welcome more physical activity in the workplace as an initiative by your employer? If so, could you give a specific example of what? The result was positive answers and respondents' interest in physical activities organized by the employer. Most respondents who answered the question would welcome more physical activities, financial benefits to support sports activities, or organized teambuildings focused on physical and sports activities as an initiative on the part of the employer. The most frequently stated interest in the following physical activities in the workplace was: yoga, pilates, swimming, stretching exercises, fitness room, joint running trainings, hiking trips, as well as organizing collective sports such as football, hockey and volleyball. If the nature of the work does not allow the organization of physical activities in the workplace, respondents would welcome a financial contribution 
to sports from the employer as a form of support for maintaining overall health. In addition to specific activities, some responses inspired activities that could be implemented. Respondents would welcome a longer lunch break, or a longer break at any time, so that they can leave the workplace for sports activities. Of course, after doing a sports activity, they would return to work, stayed longer and continued to be excited by positive energy to continue working. The application of this idea could be supported by flexible working hours, if the nature of the work allows it. In international foreign companies, flexible working hours are already commonly offered as a benefit for employees. Some said that they would welcome a mandatory break focused exclusively on physical activities during the working day. Some companies organize a popular plan challenge for employees as a form of a certain ice-break and stretching during work. The aim of this challenge is to stay as long as possible in the plank position, while competing to last the longest, especially for men, this challenge is very popular. In addition to action activities, respondents highlighted and would appreciate the opportunity to relax in the workplace through a massage, ideally a sauna.

The evaluation of data from the survey by respondents who reported the frequency of sports activities 3 times a week and more did not confirm a significant linear correlation of the impact of sports on employees' performance with those who do not perform sports often. The values of the correlation of the data concerning influence of the frequency of sport and the investigated factors expressed by using the mathematical-statistical function of linear correlation are shown in Table 1.

Table 1

Correlation between the examined factors and the frequency of sports activities

\begin{tabular}{|c|c|}
\hline Factor investigated & Linear correlation * \\
\hline Satisfaction & 0,12 \\
\hline Motivation & 0,15 \\
\hline Efficiency & 0,08 \\
\hline Attention & 0,19 \\
\hline Stress & 0,16 \\
\hline Positive mood & 0,24 \\
\hline Creativity & 0,24 \\
\hline
\end{tabular}

$* 0=$ no correlation, $1=$ linear correlation

Based on the data obtained from the survey, it follows that the greatest correlation between the researched factors and the frequency of sports activities was achieved by creativity and positive mood. From the survey we can conclude that sports activities have a certain, although not great impact, on the mood of employees and their creativity, followed by attention and stress. The survey did not confirm a significant linear correlation based on the analyzed data obtained from the respondents. It follows from the above that physical activities can affect the studied factors, but we cannot generalize and apply them to everyone. In order to achieve a greater linear correlation of the data, several variables would have to be taken into account in the research.

Conclusion. Given the high prevalence of work-related musculoskeletal disorders, it makes great sense from a business point of view to invest in the prevention of their formation or occurrence. Long-term sitting occurs in many work situations, from working in industry on assembly lines to working as cashiers in supermarkets or at a computer. In order to prevent this trend, it would be worth, on the basis of the survey and information from application practice, to include an action plan of physical activities in the workplace with one hundred employees and more, the nature of which requires sedentary work. When creating the action plan, we were inspired by the results of the survey, as well as the publication of the European Union Prize for Good Practice in the Healthy Workplaces Campaign 2016-2017 [10].

The action plan for physical activities consists of physical activities at the workplace and physical activities outside the workplace, where the employee normally resides within the employment relationship.

At the workplace, we propose the implementation of height-adjustable tables, high tables suitable for "standing meetings" and as an equipment for exercise in the form of a fitness room performing exercises such as yoga, stretching, fitness and strength training organized once a day which are demanded in the organization. Once a quarter, there should be organized seminars focused on a healthy lifestyle, which would collectively support the overall idea of the action plan of physical 
activities. Outside the workplace, organize regular collective trainings of physical activities, which are most in demand at a frequency of 2 times a week. Based on the survey, we found that the demand is mainly for the following activities: organizing collective volleyball, football, joint running training, hiking activities, or organizing collective badminton.

Through poster campaigns, employees are reminded to move and train regularly during the working day to lead a successful fight against inactivity. The anchoring of the action plan takes place in the form of small sports challenges with published results of employees, as we know that the factor of competitiveness and the element of being rewarded is sometimes stronger in motivation than the movement itself. We recommend organizing sports challenges once in 2 months.

The paper is an output within the research task VEGA no. 1/0433/20 entitled: Factors of formal and informal care in the long-term care system.

\section{References}

1. Bean, S. (2018). Lack of motivation at work impacts both performance and mental health. Retried from https://workplaceinsight.net/lack-of-motivation-at-work-impactsboth-performanceand-mental-health/. [online 2021-03-20].

2. Cotman, C., Berchold, N. (2002). Exercise: a behavioral intervention to enhance brain health and plasticity. In Trends Neurosci, 25, 6, 295-30.

3. Ghildyal, R., (2015). Mens Sana Monogr: Role of Sports in the Development of an Individual and Role of Psychology in Sports. Mens Sana Monogr, India, 170 p. ISBN 9731229.153335 .

4. Hansen, A. (2019). Ako cvičenie a pohyb posilňujú mozog. Dobehni svoj mozog: Štokholm. [In Slovak].

5. Mikas, J. (2017). Úrad verejného zdravotníctva Slovenskej republiky. Retried from https://www.uvzsr.sk/index.php?option=com_content\&view=article\&id=3149:pohybznamenazdravie\&catid=56:tlaove-spravy\&Itemid=62 PASOO, 2000. [online 2021-02-7] [In Slovak].

6. Suzuki, W., Fitzpatrick, B. (2015). Healthy Brain, Happy Life: A personal program to activate your brain \& do everything better. HarperCollins, 320 p. ISBN 9780062366801.

7. S Stikar, J., Rymeš, M., Riegel, K., \& Hoskovec, J. (2003). Psychologie ve světě práce. 1. vyd. Praha: Univerzita Karlova v Praze, Nakladatelství Karolinum, 461 p. ISBN 8024604485. [In Czech].

8. Raichlen, D., Alexander, G. (2017). Adaptive Capacity: An Evolutionary Neuroscience Model Linking Exercise, Cognition, and Brain Health. In Trends Neurosci, 40, 7, 408-421.

9. Ukropcová, B., (2017). Veda na dosah - CVTI SR Prežijeme bez pohybu? Vyplyv fyzickej (ne)aktivity na zdravie (Barbara Ukropcová). Retried from https://vedanadosah.cvtisr.sk/zdravie/ vplyv-fyzickej-neaktivity-na-zdravie-cloveka/. [In Slovak].

10. WHO Regional Office for Europe (2016). Physical activity strategy for the WHO European Region 2016-2025, Kodaň 2016, 32 p. ISBN 978-92-890-5147-7.

11. Zákon, č. 440/2015 Z. z. o športe a o zmene a doplnení niektorých zákonov http://www. zakonypreludi.sk/zz/2015-440. [In Slovak].

12. WHO: Physical activity strategy for the WHO European Region 2016 - 2025. Retried from https://www.euro.who.int/_data/assets/pdf_file/0014/311360/Physical-activitystrategy2016-2025. [online 2021- 06-14].

13. WHO: Physical activity (2021). Retried from https:/www.euro.who.int/en/health-topics/ disease-prevention/physical-activity/physicalactivity.[online 2021-06-13]. 